\title{
Zic2 Regulates Retinal Ganglion Cell Axon Avoidance of ephrinB2 through Inducing Expression of the Guidance Receptor EphB1
}

\author{
Ramee Lee, Timothy J. Petros, and Carol A. Mason \\ Departments of Pathology and Cell Biology, and Neuroscience, Columbia University, College of Physicians and Surgeons, New York, New York 10032
}

\begin{abstract}
The navigation of retinal axons to ipsilateral and contralateral targets in the brain depends on the decision to cross or avoid the midline at the optic chiasm, a critical guidance maneuver that establishes the binocular visual pathway. Previous work has identified a specific guidance receptor, EphB1, that mediates the repulsion of uncrossed axons away from its ligand, ephrinB2, at the optic chiasm midline (Williams et al., 2003), and a transcription factor Zic2, that, like EphB1, is required for formation of the ipsilateral retinal projection (Herrera et al., 2003). Although the reported similarities in localization implicated that Zic2 regulates EphB1 (Herrera et al., 2003; Williams et al., 2003; Pak et al., 2004), whether Zic2 drives expression of EphB1 protein has not been elucidated. Here we show that EphB1 protein is expressed in the growth cones of axons from ventrotemporal (VT) retina that project ipsilaterally and that repulsion by ephrinB2 is determined by the presence of this receptor on growth cones. Moreover, ectopic delivery of Zic2 into explants from non-VT retina induces expression of EphB1 mRNA and protein. The upregulated EphB1 receptor protein is localized to growth cones and is functional, because it is sufficient to change retinal ganglion cell axon behavior from extension onto, to avoidance of, ephrinB2 substrates. Our results demonstrate that Zic2 upregulates EphB1 expression and define a link between a transcription factor and expression of a guidance receptor protein essential for axon guidance at the vertebrate midline.
\end{abstract}

Key words: retinal ganglion cell; optic chiasm; midline; ipsilateral retinal projection; guidance factor; intermediate target; axon guidance

\section{Introduction}

Axons are instructed by intrinsic and extrinsic cues to project over long distances, undergo complex spatial maneuvers at intermediate targets, and reach their final destinations with unerring precision. The CNS midline is an important intermediate target that navigating axons either traverse or avoid, a crucial decision that allows the nervous system to coordinate events impinging on each side of the body.

The optic chiasm is a midline decision point at which retinal axons from each eye diverge to project to targets in the same or the opposite brain hemispheres to pattern binocular vision. Recent studies have uncovered a specific axon guidance receptor, the receptor tyrosine kinase EphB1, whose mRNA is expressed exclusively in retinal ganglion cells (RGCs) located in the ventrotemporal (VT) retina, a source of the ipsilateral retinal projec-

Received Feb. 12, 2008; revised April 4, 2008; accepted April 22, 2008.

This work was funded by National Institutes of Health Grants F32 EY016284 (R.L), F31NS051008 (T.J.P.), and R01 EY12736 and EY01529 (C.M). We thank Eloisa Herrera and Cristina García-Frigola for their insightful input to the experimental design and preparation of this manuscript and for the Zic2-Sindbis constructs. We are grateful to Zaven Kaprielian for the generous gift of EphB1 antibody, Mark Henkemeyer for the EphB1 KO mice, Peter Schieffele, Hynek Wichterle, and Fiona Doetsch for sharing facilities, and Larry Kromer, Jane Dodd, and Sara Wilson for helpful discussion. We thank members of the Mason laboratory, especially Emily Baneman and Alexandra Rebsam, for critically reading this manuscript, and Rich Blazeski and Mika Melikyan for expert technical assistance.

Correspondence should be addressed to Ramee Lee, Departments of Pathology and Cell Biology, and Neuroscience, Columbia University, College of Physicians and Surgeons, 14-509 P\&S Building, 630 West 168th Street, New York, NY 10032. E-mail: rl2159@columbia.edu.

D0I:10.1523/JNEUROSCI.0632-08.2008

Copyright $\odot 2008$ Society for Neuroscience $\quad 0270-6474 / 08 / 285910-10 \$ 15.00 / 0$ tion; its ligand, ephrinB2, is expressed by radial glial cells at the chiasm midline (Williams et al., 2003). An important question is whether EphB1 protein is localized to growth cones of ipsilaterally projecting RGCs as they encounter ephrinB 2 and how the expression of this receptor is controlled.

Numerous receptor-ligand pairs direct axon divergence at midline decision regions, including the Ephs-ephrins, deleted in colorectal cancer (DCC)-netrins, Robos-slits, and Neuropilins/ Plexins-semaphorins, but the regulation of the expression of these receptors is not well understood (Williams et al., 2004; Dickson and Gilestro, 2006). It is becoming clear that hierarchies of transcription factors specify neuronal subpopulations and provide molecular programs for directing axonal trajectories to targets, by regulating the expression of guidance receptors and cues on navigating axons at their intermediate and final targets (Jessell, 2000; Shirasaki and Pfaff, 2002; Butler and Tear, 2007; Polleux et al., 2007). Although progress has been made in characterizing the transcriptional regulation of guidance molecules in motor neurons during projection to targets in the limb (Kania and Jessell, 2003; Broihier et al., 2004; Labrador et al., 2005), only one example of this relationship has been identified at midline intermediate targets, in invertebrates. In Drosophila, the transcription factor Lola regulates both Robo receptor and Slit ligand levels to mediate axonal crossing at the midline (Crowner et al., 2002).

In the retina-chiasm midline model, the zinc finger transcription factor Zic2 has been implicated in the determination of ax- 
onal laterality at the vertebrate optic chiasm. Like EphB1, Zic2 is necessary for the ipsilateral retinal projection. Zic2 expression overlaps with EphB1 transcript expression spatially and temporally within VT retina (Herrera et al., 2003; Williams et al., 2003; Pak et al., 2004; García-Frigola et al., 2008). This coincident expression suggests that Zic2 might be in a position to regulate EphB1, but whether Zic2 elicits the expression of EphB1 protein has not been elucidated.

Here we show that EphB1 protein is expressed on ipsilaterally projecting retinal growth cones during repulsion away from the midline cue, ephrinB2, in an in vitro setting. Second, Zic2 is sufficient to induce the expression of EphB1 mRNA and protein even in cells not normally expressing Zic2 or EphB1 and to change the behavior of retinal axons from extension into, to repulsion away from, its relevant midline cue ephrinB2. These data highlight a link, in vertebrates, of transcription factor regulation of a guidance receptor used in decision making at the CNS midline.

\section{Materials and Methods}

Animals. Embryos from C57BL/6J and EphB1 $1^{-1-}$ mice (Williams et al., 2003) kept in a timed pregnancy breeding colony at Columbia University were removed from anesthetized mothers by cesarean section, with embryonic day 0 (E0) defined as midnight on the day a plug was found. Animals were treated according to National Institutes of Health Guidelines for the Care and Use of Laboratory Animals. Animal protocols were approved by the Institutional Animal Care and Use Committee of Columbia University.

Retinal explant cultures. Retinal explants from E14.5 embryos were dissected and cultured as described previously (Wang et al., 1995). Retinal quadrants from peripheral regions of VT and dorsotemporal (DT) retina were then plated (ganglion cell-side down) onto $12 \mathrm{~mm}$ glass coverslip-bottom dishes (MatTek) coated sequentially with $0.01 \%$ polyornithine (Sigma) for $2 \mathrm{~h}$ at $37^{\circ} \mathrm{C}$, followed by $10 \mu \mathrm{g} / \mathrm{ml} \mathrm{laminin} \mathrm{(Invitro-}$ gen) for $2 \mathrm{~h}$ at $37^{\circ} \mathrm{C}$. Explants were grown at $37^{\circ} \mathrm{C} / 5 \% \mathrm{CO}_{2}$ for $18 \mathrm{~h}$ and then fixed for $20 \mathrm{~min}$ with $4 \%$ paraformaldehyde (PFA) plus $100 \mu \mathrm{M}$ sucrose.

To assess EphB1 mRNA in axonal versus cell body compartments, retinal explants from E14.5 embryos were cultured for $30 \mathrm{~h}$ on scratched MatTek dishes, coated as above with $0.01 \%$ polyornithine and laminin. Axons grow in cohorts on scratched parallel lanes, allowing for ready collection of axons separated from cell bodies. Axons were severed using a sterile microblade at least $300 \mu \mathrm{m}$ from their cell bodies. Cell bodies were collected first, and then any remnant cell body material and the proximal axonal segments were vacuum aspirated. Then, axons distal to the cut were collected and pooled, and reverse transcription (RT)-PCR was conducted as below.

Sindbis virus constructs and virus infection. Sindbis viruses enhanced green fluorescent protein (EGFP) (GFP virus) and Zic2-internal ribosomal entry site (IRES)-EGFP (Zic2 virus) were generated according to the Sindbis Expression System, Version E (Invitrogen). A modified version of the virus that can deliver genes into RGCs at high efficiencies of infection with decreased cytotoxicity was used (Herrera et al., 2003).

Retinal explants taken from E14.5 embryos were incubated in a solution of Sindbis virus in serum-free medium for $60 \mathrm{~min}$ at $37^{\circ} \mathrm{C}$. Excess virus was removed by washing four times with serum-free medium. Explants were then plated, and, after $18 \mathrm{~h}$ in culture, allowing for the full extension of axons and growth cones, explants and neurites were harvested for Western blotting or RT-PCR analysis, or cultures were fixed in $4 \%$ PFA for immunohistochemistry (IHC). On average, the infection efficiency of both Zic2 and GFP viral constructs was 80-90\%. Only those explants exhibiting $>80 \%$ GFP fluorescence were analyzed.

Western blot analysis and preabsorption of antibody. To detect EphB1 protein, Western blot analysis was performed on lysates taken from E14.5 VT retinal explants cultured in vitro for $18 \mathrm{~h}$, following standard protocols using an antibody to EphB1 (4A7 or mAb EfB1-EfB3, made against EphB1-Fc; gift from Zaven Kaprielian, Albert Einstein School of Medi- cine, Bronx, NY) (Jevince et al., 2006). Retinal cultures were homogenized with a sonicator in lysis buffer ( $50 \mathrm{~mm}$ Tris- $\mathrm{HCl}, \mathrm{pH}$ 7.4, $5 \mathrm{~mm}$ DTT, $1 \% \mathrm{NP}-40$, and $5 \mu \mathrm{g} / \mathrm{ml}$ leupeptin, aprotinin, and pepstatin). The protein content of the supernatant was determined by the BCA protein assay kit (Bio-Rad). Samples (30 $\mu$ g of protein) were added to SDS sample loading buffer, electrophoresed in 10\% SDS-polyacrylamide gels under reducing conditions, and transferred to polyvinylidene difluoride membranes. The membranes were incubated in 5\% nonfat milk overnight at $4^{\circ}$ and then incubated for $24 \mathrm{~h}$ at $4^{\circ}$ in primary antibody (4A7), $2 \mathrm{~h}$ at room temperature for all other antibodies, and $2 \mathrm{~h}$ room temperature for secondary antibodies.

To eliminate cross-reactivity from EphB2 and EphB3 (Jevince et al., 2006), the EphB1 antibody was preabsorbed with EphB2-Fc and EphB3-Fc fusion proteins (R\&D Systems) (details of preabsorption protocol in the study by Bundesen et al., 2003). Anti- $\beta$-tubulin antibody (monoclonal, T 5293, clone 2-28-33; Sigma) was used as a loading control.

RT-PCR. For each condition, total RNA was extracted from 12-14 pooled E14.5 retinal explants, and their neurites were grown $18 \mathrm{~h}$ in culture. For cell body versus axonal compartment experiments, RNA was purified from 24 pooled E14 explants to obtain adequate starting material for investigations of EphB1 mRNA in axonal compartments. Explants were either uninfected or infected with EGFP or Zic2-Sindbis virus. Total RNA was purified using RNAeasy Mini kit (Qiagen), according to the instructions of the manufacturer, including an on-column DNAase digestion to remove potential genomic DNA contamination. Pooled explants or axons alone were placed directly into $200 \mu$ lof lysis buffer (Buffer RLT as provided by Qiagen) containing $1 \%$ fresh $\beta$-mercaptoethanol and used directly for RNA extraction. RT-PCR was performed following the instructions of the manufacturer (Invitrogen). Total RNA and DNA concentrations were measured by nanodrop spectrometry. Specific primers to amplify EphB1 were designed as in the study by Vidovic and Marotte (2003), and $\beta$-actin primers ( $\beta$-actin forward, tagagggaaatcgtgcgtgacat; $\beta$-actin reverse, accgctcgttgccaatagtgatga) were used to confirm equal starting material for PCR reactions. As a positive control, EphB1 plasmid DNA was used as template, and, as a negative control, water was used. PCR products were electrophoresed in $2 \%$ agarose gels stained with ethidium bromide and visualized on a UV transilluminator.

Immunohistochemistry with quantification offluorescence. Immunohistochemistry using EphB1 antibodies (4A7) (Jevince et al., 2006), preabsorbed as above to eliminate cross-reactivity to EphB2 and B3, was used at 1:50 to stain RGC growth cones on neurites extending from retinal explants, taken from E14.5 animals. Anti-doublecortin and anti-GAP-43 antibody (Millipore Bioscience Research Reagents) were used at 1:1000 to stain retinal neurites. Retinal cultures were fixed after $18 \mathrm{~h}$ in vitro in $4 \%$ PFA, permeabilized with $0.1 \%$ Triton X-100, blocked in $10 \%$ goat serum, and then immunostained with primary antibodies, followed by cyanine 3 (Jackson ImmunoResearch) or Alexa Fluor488 (Invitrogen) secondary antibodies. GAP-43 staining was used to highlight growth cones, and growth cone outlines were traced using Openlab image analysis software to quantify total fluorescent intensity. EphB1-positive fluorescent puncta were visualized using $4 \mathrm{~A} 7$ antibody within the same growth cone. The ratio of EphB1 fluorescence/total growth cone fluorescence was determined for a total of 58-72 growth cones per condition. Exposure times were kept constant, and growth cones selected for analysis were chosen randomly. Quantitations were performed blinded to condition. Error bars represent SEM, and statistical analysis was determined using two-tailed Student's $t$ test.

Assays of explant neurite growth. A half-dish culture assay was used to quantify retinal axon response to ephrinB2. The entire coverslip in the well was coated with polyornithine (Sigma) and then laminin (Invitrogen). Clustered ephrinB2-Fc mixed with BSA conjugated to Alexa Fluor 488 (1:100; Invitrogen) to visualize the border/ephrinB2 zone was applied to one-half of the coverslips (as described by Petros et al., 2006). EphrinB2-Fc $(0.5 \mu \mathrm{g} / \mathrm{ml}$; Regeneron) was clustered as described by Williams et al. (2003). The retinal explants were plated in serum-free medium with $0.4 \%$ methylcellulose on the laminin-only, ephrinB2-free half of the well. Neurites were visualized with doublecortin antibody (poly- 
clonal guinea pig; Millipore Bioscience Research Reagents). The total area covered by neurites was quantified with Openlab image analysis software.

The diagram in Figure $2 \mathrm{~A}$ illustrates method of calculation; the green shaded area (Alexa Fluor 488) represents the border. To normalize for the variability in distances between the explants and borders, we made a circle using Openlab image analysis software, with the radius from the center of the explant to the border of ephrinB2 and excluded neurites within this circle (described in supplemental Fig. 1, available at www.jneurosci.org as supplemental material). For analysis, a ratio of "neurite fluorescence within the border region/total axonal area" was quantified. Error bars represent SEM, and statistical analysis was determined using two-tailed Student's $t$ test.

\section{Results}

EphB1 receptor protein is expressed in growth cones of ventrotemporal (uncrossed) retinal ganglion cells

Although our previous report suggested a key role of EphB1 in the formation of the ipsilateral projection, we had examined only mRNA levels in retinal cell bodies (Williams et al., 2003). To assess whether EphB1 protein is expressed in the growth cones of VT retinal axons, the only RGCs that express EphB1 mRNA, we used a monoclonal EphB1 antibody (Jevince et al., 2006) in both IHC and Western blot analysis of retinal explants plated on polyornithine/laminin without ephrinB2. By IHC, at E14.5-E15.5, the time when VT axons in mouse reach the chiasm midline, EphB1 protein is expressed exclusively on VT growth cones and not on the growth cones of axons emanating from explants from contralaterally projecting regions of the retina, here, DT retina (Fig. $1 A$, left). Growth cones extending from either VT or DT RGC explants from EphB1 $1^{-/-}$mice do not exhibit EphB1 staining in VT or DT growth cones (Fig. $1 A$, right).

To confirm the specificity of the EphB1 antibody, we used antibody preabsorption techniques, because this EphB1 antibody is known to have some cross-reactivity to EphB2 and EphB3 (Jevince et al., 2006). When the EphB1 antibody was preabsorbed with EphB1-Fc fusion protein, staining in VT growth cones completely disappeared (Fig. $1 B$, second column), in contrast to unabsorbed antibody (Fig. $1 A$, leftmost two columns). Thus, because growth cone staining is absent after preabsorbing the antibody with EphB1-Fc as well as in EphB1 ${ }^{-/-}$growth cones, we conclude that the growth cone staining represents specific signal for $\mathrm{EphB1}$ protein. It should be noted that there is some residual staining in the shafts of these axons that does not disappear after antibody preabsorption with EphB1 and that can also be detected in $E p h B 1^{-1-}$ axons. However, this staining appears to be nonspecific and unrelated to the
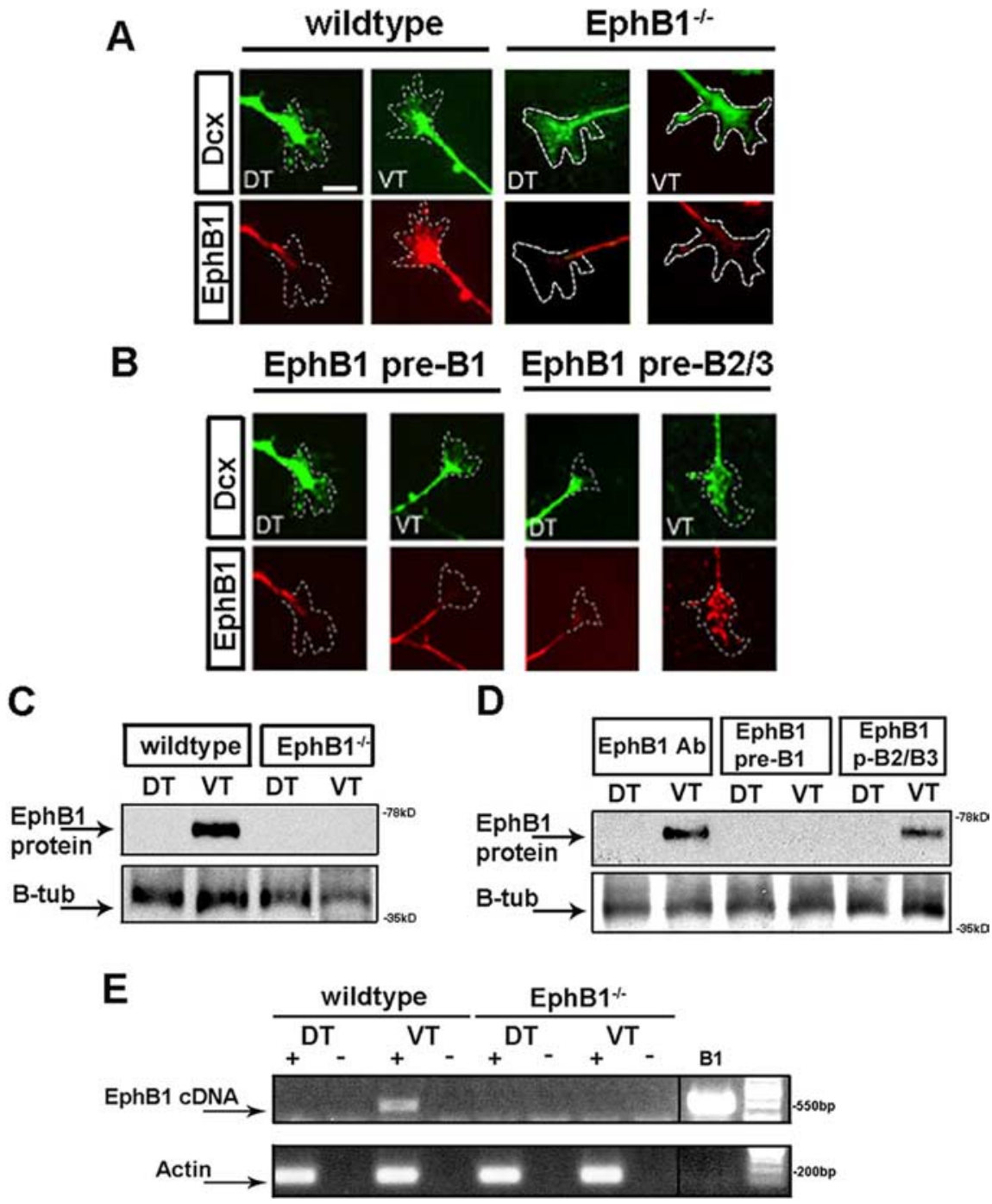

Figure 1. EphB1 protein is expressed in growth cones of ventrotemporal (uncrossed) but not dorsotemporal (crossed) retinal ganglion cell growth cones. $\boldsymbol{A}$, IHC of growth cones from DT and VT retinal explants from wild-type or EphB1 ${ }^{-/-}$E14.5 animals cultured for $18 \mathrm{~h}$ and double stained with doublecortin (green) and with anti-EphB1 (4A7) antibodies (red). Differential interference contrast microscopy was used to outline the morphology of growth cones. EphB1 protein is endogenously expressed in VT but not DT growth cones. In retinal growth cones from $E \mathrm{phB1}{ }^{-1-}$ animals, endogenous EphB1 receptor protein is not expressed in either DT orVT growth cones. Scale bar, $10 \mu \mathrm{m}$. $\boldsymbol{B}, \mathrm{IHC}$ of retinal growth cones from E14.5 DT or VT explants, stained with preabsorbed EphB1 antibody to demonstrate the specificity of this antibody to EphB1 protein in retinal growth cones. In left panels, when EphB1 antibody is preabsorbed with EphB1-Fc, staining in VT growth cones is eliminated (compare with unabsorbed antibody in VT, left panel in $A$ ), demonstrating that this antibody recognizes EphB1 protein in RGC growth cones. After preabsorbing the EphB1 antibody with EphB2-Fcand EphB3-Fc fusion proteins (see Materials and Methods), staining intensity remains similar in growth cones compared with staining with EphB1 antibody alone. The EphB1 antibody preabsorbed with EphB2/EphB3-Fc was used in experiments shown in subsequent figures. C, Western blot analysis of RGC lysates $(30 \mu \mathrm{g})$ taken from E14.5 DT and VT retina grown in culture for $18 \mathrm{~h}$. EphB1 protein is detected in VT lysates and not in DT lysates from wild-type retinas. In retinal lysates taken from EphB1 ${ }^{-1-}$ embryos, this EphB1 band is not detected in either DT or VT retina. $\beta$-Tubulin antibody was used as loading controls. D, Western blot analysis using EphB1 antibody preabsorbed with EphB1-Fc abolishes the EphB1-specific band in VT retina (middle lanes), confirming that this antibody specifically recognizes EphB1 protein as a $65 \mathrm{kDa}$ band in Western blots of retinal lysates. To assess whether this antibody detects EphB2 or EphB3, we preabsorbed with EphB2/EphB3-Fc (right lanes) and found very little difference in band intensity compared with unabsorbed EphB1 antibody (left lanes). This EphB2/EphB3-Fc preabsorbed antibody was used for Western blot analysis in subsequent figures. E, RT-PCR ofDT and VT retinal explants taken from E14.5 wild-type and EphB1 ${ }^{-/-}$embryos. EphB1 mRNA is detected in wild-type VT lysates but not in DT lysates. EphB1 is not detected in either DT orVT retina from EphB1 ${ }^{-1-}$ retina. - lanes indicate omission of reverse transcriptase performed in parallel. A plasmid bearing EphB1 coding sequence is used as a positive control (B1), and actin was amplified to confirm equal starting material of samples.

detection of EphB1 protein, as evidenced by the analysis of EphB1 $1^{-/-}$axons.

To determine whether any signal is derived from EphB2/ EphB3, the antibody was preabsorbed with EphB2-Fc and EphB3-Fc fusion proteins (see Materials and Methods). There was no difference in staining of RGC growth cones using anti- 
body preabsorbed with EphB2/B3-Fc (Fig. $1 B$, rightmost two columns) compared with staining with the unabsorbed antibody (Fig. $1 \mathrm{~A}$, leftmost two columns). Furthermore, IHC of $E p h B 2^{-/-} / E p h B 3^{-/-}$retinal explants shows staining patterns similar to that of wild-type retina (data not shown), further confirming that the EphB1 antibody specifically recognizes EphB1 in VT RGC growth cones, with little or no contribution from EphB2 or EphB3. For all subsequent experiments, we used the EphB1 antibody preabsorbed with EphB2/EphB3-Fc.

Western blot analysis was used to demonstrate expression of endogenous EphB1 receptor protein. Lysates were collected from E14.5 DT or VT explants cultured for $18 \mathrm{~h}$ on laminin/polyornithine to allow for full extension of axons and growth cones. Lysates harvested from VT explants, axons and growth cones, but not DT lysates, contain EphB1 protein (Fig. 1C). In confirmation of the IHC results, EphB1 protein is not detected in lysates taken from either VT or DT regions of $E p h B 1^{-1-}$ retina (Fig. $1 C$ ) or when the EphB1 antibody was preabsorbed with EphB1-Fc (Fig. $1 D$, middle lanes). Western blots probed with the EphB1 antibody preabsorbed with EphB2/EphB3-Fc show no difference in band intensity compared with unabsorbed EphB1 antibody (Fig. $1 D$, compare right two lanes with left two lanes), demonstrating again that very little EphB2/EphB3 protein contributes to the signal in VT retina.

Finally, we demonstrated the expression of endogenous EphB1 mRNA of retinal explants taken from wild-type and EphB1 ${ }^{-1-}$ mice, cultured for $18 \mathrm{~h}$ to allow for the extension of axons and growth cones, by RT-PCR. RNA was harvested from both wild-type VT and DT retinal explants and neurites, and PCR was performed using specific primers to detect EphB1 cDNA (Vidovic and Marotte, 2003). VT explants and neurites express EphB1 mRNA, whereas an EphB1-specific band is not detected in DT explants (Fig. 1E). EphB1 mRNA is not detectable in EphB1 ${ }^{-1-}$ RGCs after RT-PCR. These RT-PCR results support the protein analysis for detecting endogenous EphB1 and demonstrate that EphB1 is expressed in wild-type VT retina and not DT retina, nor in EphB1 $1^{-/-}$tissue.

These data provide evidence that endogenous EphB1 receptor protein as well as its transcript is expressed exclusively in VT retina, axons, and growth cones that constitute the ipsilateral projection and not in DT retina that gives rise to the crossed projection.

\section{EphB1 expression on RGC growth cones mediates the avoidance of the midline cue ephrinB2}

To determine whether EphB1 protein on VT growth cones is expressed during the repulsion of ipsilateral axons away from the midline cue ephrinB2, we used a reductionist in vitro border assay that allows us to reconstitute the interactions and behavior of retinal axons at the chiasm midline (Petros et al., 2006). Retinal explants from either wild-type or EphB1 ${ }^{-1-}$ E14.5 animals were cultured proximal to the border of a zone of ephrinB2 (see Materials and Methods), allowing RGC growth cones and axons to encounter the ligand ephrinB2. Retinal explants were stained with doublecortin antibody (red) to visualize axons. $\sim 38 \%$ of DT explant axons extend into the ephrinB2 border region (at least 12 explants from 4 independent experiments per condition) (Fig. $2 A$, top left), reflecting the in vivo scenario in which contralaterally projecting DT axons traverse the chiasm midline. The remaining $62 \%$ of DT axons that do not encounter the ephrinB2 zone continue to grow in a radial manner. In contrast, VT axons, which are normally repulsed by the midline cue in vivo, are inhibited from entering ephrinB2 borders, with $<7 \%$ of total VT axons projecting into ephrinB2 regions (Fig. $2 \mathrm{~A}$, top right; quantifications in $B$ ).

If repulsion away from ephrinB2 is mediated by EphB1 expressed in VT growth cones, then VT retinal explants taken from $E p h B 1^{-1-}$ animals should not be inhibited by the border of ephrinB2. Indeed, $27.5 \%$ of VT axons from EphB1 $1^{-1-}$ animals project into the ephrinB2 region, demonstrating that the EphB1 receptor is required for repulsion of this midline cue (Fig. $2 \mathrm{~A}$, bottom). Axons from DT EphB1 $1^{-/-}$explants also grow freely into the ligand border, with $36 \%$ of their axons entering border regions. It is notable that there is a slight increase in $\mathrm{VT} \mathrm{EphB1^{-/- }}$ axons that avoid the border compared with DT wild-type or DT $E p h B 1^{-1-}$ explants, indicating that there may be other receptors on RGCs in VT retina to ephrinB2 that are not expressed in dorsal regions. To demonstrate that the repulsive response of VT retina is specific to ephrinB2 ligand, when explants are plated along an Fc border alone, $>35 \%$ of axons from either DT or VT explants from wild-type or EphB1 $1^{-1-}$ retina, cross through the border (data not shown).

To characterize the expression of EphB1 protein on RGC neurites during repulsion by ephrinB2, immunohistochemistry was performed, using the preabsorbed anti-EphB1 antibody described above. EphB1 protein (red) is expressed on growth cones from VT retina as axons approach ephrinB2 borders (Fig. 2C, left) and as they turn away and grow parallel to borders during avoidance of ephrinB2 regions (Fig. 2C, right). EphB1 protein is not detected on DT explant growth cones as they enter into ephrinB2 regions (Fig. 2D), because doublecortin shows a full, extended growth cone in the same field.

\section{Ectopic expression of Zic2 upregulates EphB1 in retinal explants}

We have reported previously that Zic2 is expressed in a similar spatiotemporal pattern as EphB1 exclusively in VT cell bodies, during the period when retinal growth cones reach the midline, E14.5-E17.5. The expression of Zic2 briefly precedes and then overlaps with EphB1 expression, and Zic2 is essential for the formation of the ipsilateral projection (Herrera et al., 2003; Pak et al., 2004; García-Frigola et al., 2008). To determine whether the localization of these two molecules is purely coincidental or whether Zic2 serves to regulate the expression of EphB1 in embryonic retina, we ectopically introduced Zic2 by recombinant viral delivery in DT and VT explants from wild-type and $E p h B 1^{-1-}$ retinal explants cultured in vitro and analyzed EphB1 expression at both the mRNA and protein levels. Retinal explants infected with EGFP-Sindbis virus (GFP virus) or with Zic2IRES-EGFP-Sindbis virus (Zic2 virus) (Herrera et al., 2003) were cultured for $18 \mathrm{~h}$ on a laminin/polyornithine substrate and then harvested, including axons and growth cones emanating from the explant. EphB1 mRNA is detected in VT explants infected with GFP virus but not DT explants (Fig. 3A). In DT explants infected with Zic2 virus, EphB1 mRNA is upregulated in these quadrants, which normally do not express EphB1, as well as in VT explants (Fig. 3A). To confirm that Zic2 is acting on the EphB1 gene, we analyzed EphB1 ${ }^{-1-}$ DT and VT retinal explants and did not amplify an EphB1 band (Fig. 3A). These results show that the exogenous delivery of Zic2 into a region of the retina that does not endogenously express Zic2 or EphB1 can induce the expression of EphB1 mRNA.

To determine whether the mRNA for EphB1 produced at the cell body level becomes localized to axonal compartments, we harvested mRNA from axons and growth cones separately from cell bodies after Zic2 virus and GFP virus infection. In agreement 

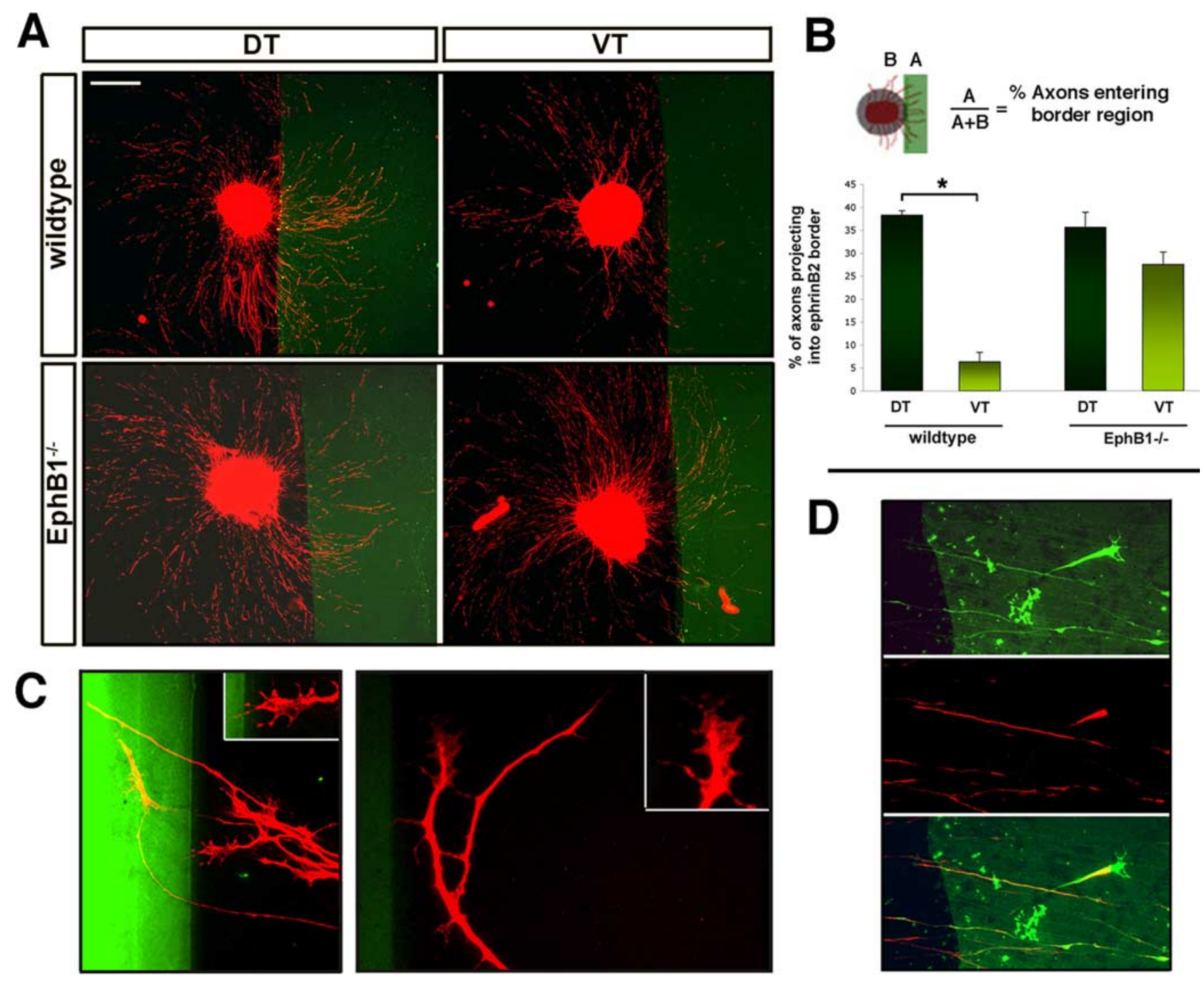

Figure 2. Expression of EphB1 receptor protein mediates the avoidance of VT growth cones to the midline cue, ephrinB2.A, In vitro assays of E14.5 retinal explants stained with doublecortin (red) confronted with ephrinB2 borders (green). Top left demonstrates that axons from the DT quadrant of wild-type retina enter the ephrinB2 border region in vitro, reflecting their ability to cross the chiasm midline in vivo. Axons emanating from the VT quadrant of retina (top right) are inhibited by ephrinB2 and avoid entering into ephrinB2 zones, thus mimicking the in vivo scenario in which these axons are repulsed by ephrinB2 at the chiasm midline. The bottom row shows two representative retinal explants taken from EphB1 ${ }^{-/-}$animals. DT EphB1 ${ }^{-/-}$axons enter freely into the ephrinB2 border, and the repulsion observed in wild-type VT axons is abrogated in EphB1 $1^{-1-}$ VT explants, although some avoidance remains in EphB1 ${ }^{-1-}$ VT axons. Scale bar, $500 \mu \mathrm{m} . \boldsymbol{B}_{\text {, }}$ Quantification of the proportion of RGC axons that enter the border region. Diagram illustrates the method of calculation, in which the green shaded area represents the ephrinB2 border. We quantified the fluorescence of axons entering the border region compared with the total fluorescence of all axons combined, subtracting fluorescence from the explant cell bodies and normalizing for their distance from the border (for details, see supplemental Fig. 1, available at www.jneurosci.org as supplemental material). In DT explants, $\sim 38 \%$ of total axons enter into the ephrinB2 zone, whereas only $6 \%$ of axons from VT explants project across the border. In retinal explants taken from EphB1 ${ }^{-1-}$ animals, $\sim 35 \%$ of DT axons enter the ephrinB2 region, and $28 \%$ of VT axons project through ephrinB2, exhibiting some avoidance $(p<0.05) . n>12$ explants for each condition, in 4 independent experiments. Error bars indicate SEM. ${ }^{*} p<0.0005$. C, Higher magnification $(63 \times)$ of VT growth cones as they approach (left) and turn away (right) from ephrinB2 border. EphB1 antibody (red) and ephrinB2 borders (green). VT growth cones express EphB1 receptor protein, as seen in the insets. D, DT axons entering ephrinB2 borders. A single growth cone in this field is visualized by doublecortin staining (green, top). This growth cone does not express EphB1 protein (red, middle), as shown in the merged image (bottom).

with measures of whole DT explants infected with Zic2 virus (Fig. $3 A$ ), EphB1 mRNA is found in the cell body compartment (Fig. $3 B$, lane 5). Interestingly, EphB1 mRNA is also localized to the distal axonal compartment (Fig. $3 B$, lane 6). This result indicates that Zic2 activates transcription of EphB1 mRNA in the cell nucleus and that EphB1 mRNA is transported down to the axon terminus.

\section{EphB1 protein is upregulated in retinal growth cones after} ectopic delivery of $\mathrm{Zic} 2$

To determine whether Zic2 delivery can drive EphB1 protein expression, we examined EphB1 expression by Western blot anal- ysis and IHC in retinal growth cones after infection with GFP or with Zic2 virus. Western blot analysis was performed after infection of GFP or Zic2 virus into wild-type and EphB1 $1^{-/-}$explants to determine EphB1 protein levels. We observed an upregulation of EphB1 protein in DT explants after Zic2 delivery (Fig. 4A, lane 2 ), whereas infection with GFP virus did not induce EphB1 protein in DT retinal lysates (Fig. 4A, lane 4). EphB1 protein was not detected in $E p h B 1^{-/-}$tissue infected with Zic2 virus. Together, these data reveal that Zic2 is a transcriptional regulator of EphB1 and that Zic2 can upregulate EphB1 message and protein in retinal regions that normally do not express Zic2 or EphB1.

For immunohistochemistry, an antibody to GAP-43 was used 


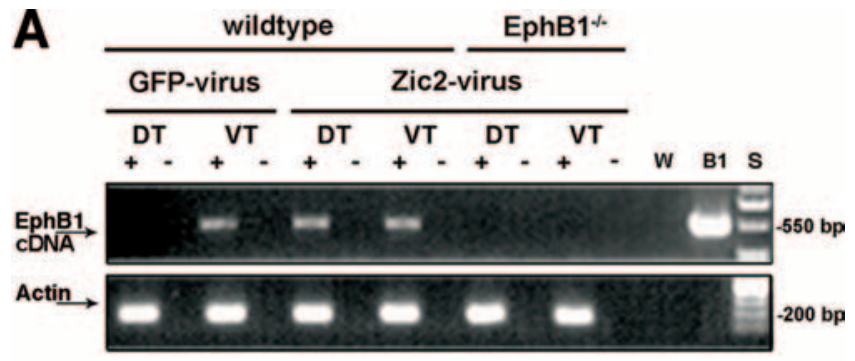

B

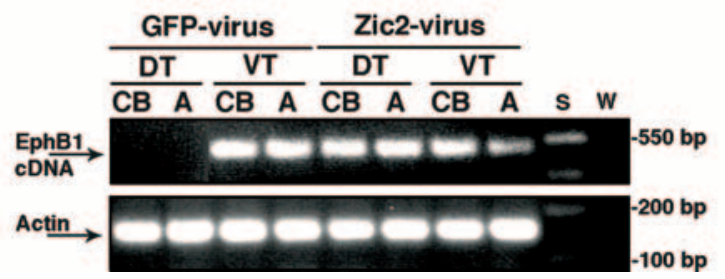

Figure 3. Ectopic expression of Zic2 in vitro induces EphB1 mRNA. A, RT-PCR of DT or VT explants taken from E14.5 wild-type embryos and infected with EGFP (GFP virus) or Zic2-IRESEGFP Sindbis virus (Zic virus). EphB1 mRNA is detected in GFP virus-infected VT explants but not in DT explants, as in uninfected conditions. After infection of DT explants with Zic2 virus, there is an upregulation of EphB1 mRNA. Infection of $E p h B 1^{-/-}$retina with Zic2 virus does not induce EphB1 mRNA expression. - lanes indicate negative controls performed in parallel omitting reverse transcriptase. As a negative control, water was used as template (W). As a positive control, a plasmid bearing the EphB1 coding sequence was used as template (B1). A nanodrop spectrometer was used to measure both RNA and CDNA starting material levels, and actin was amplified as an additional confirmation of equal starting material of samples. $\boldsymbol{B}, \mathrm{RT}-\mathrm{PCR}$ to detect EphB1 mRNA in cell body compartments (CB) compared with axonal compartments (A) of DT or VT explants taken from E14.5 wild-type embryos infected with GFP virus or Zic2 virus. Explants were grown for $30 \mathrm{~h}$, and axons extending in scratched lanes were isolated separately from cell bodies. As in A, EphB1 mRNA is not detected in GFP-virus infected DT explants, in either cell bodies or axonal compartments, but EphB1 mRNA is detected in axons from VT explants as well as VT cell bodies after GFP virus infection. After infection with Zic2 virus, EphB1 mRNA is upregulated in DT cell bodies and in axons. Water (W) was used as a negative control and (S) standard molecular weight marker.

to outline the morphology of RGC growth cones and to quantitatively measure the total growth cone fluorescence, and EphB1 fluorescent puncta were quantified using the EphB1 antibody. EphB1 protein was detected in VT growth cones infected with GFP virus, but staining for EphB1 was absent in DT growth cones (Fig. $4 B a^{\prime}, B b^{\prime}$ ). Measures of a ratio of EphB1 fluorescence over total growth cone fluorescence showed that DT growth cones exhibit $<3 \%$ EphB1 fluorescence, whereas EphB1 fluorescence in VT growth cones encompasses $25 \%$ of total growth cone fluorescence (Fig. 4C). Greater than 58 growth cones were analyzed per condition and pooled from three independent experiments. In contrast, in growth cones of DT explants infected with Zic2, EphB1 protein expression increased to 22\% EphB1 (Fig. $4 B c^{\prime}$ ), paralleling the levels and punctate expression pattern seen in both uninfected VT growth cones as well as VT growth cones infected with Zic2, at $24 \%$ of total growth cone fluorescence (Fig. $\left.4 B d^{\prime}\right)$. No EphB1 staining was detected after Zic2 induction in either DT (3\% EphB1 of total fluorescence) or VT (5\% total fluorescence) growth cones from $E p h B 1^{-/-}$retinal explants, similar to uninfected $E p h B 1^{-/-}$growth cones (Fig. $4 B e^{\prime}, B f^{\prime}$ ). Relative EphB1 fluorescence levels are quantified in Figure $4 C$.

These results indicate that EphB1 protein is expressed in the growth cones of ipsilateral but not contralateral axons and that ectopic expression of Zic2 specifically upregulates EphB1 protein in DT growth cones. Interestingly, Zic2 delivery into VT tissue does not result in a combined effect of endogenous EphB1 protein plus ectopic EphB1 induction. This was observed in both Western blots (Fig. 4A) and growth cone immunostaining (Fig. $4 B)$. These results suggest that there may be a "ceiling" of EphB1 protein expression that cannot be exceeded within a given neuron/growth cone at a particular time.

Zic2 ectopic expression is sufficient to switch the behavior of retinal axons from extension on to repulsion by ephrinB2 through the induction of EphB1

We have shown by both Western blot analysis and immunohistochemistry of growth cones that Zic2 drives the upregulation of mRNA as well as protein expression for EphB1 in retinal explants. Next, we investigated whether ectopic expression of Zic2 induces upregulation of functional EphB1 on retinal axon growth cones to mediate repulsion of ephrinB2 in the border assay. Explants from E14.5 DT or VT retina were infected with either GFP or Zic2 virus and cultured alongside a border of ephrinB2 substrate. Nearly all axons from non-infected or GFP-infected VT explants avoided the ephrinB2 borders ( $<5 \%$ of axons project into borders, analysis performed on 18 explants pooled from five independent experiments), whereas axons from non-infected and GFP-infected DT explants extend freely through the border $(36 \%$ of total axons) (Fig. 5A, top two panels; quantified in $B$ ). After infection with $\mathrm{Zic} 2$ virus, axons from $\mathrm{VT}$ retina continue to avoid the ephrinB2 border, with only $4 \%$ of total axons crossing the ephrinB2 border (Fig. 5A, middle row, right panel). Remarkably, axons from DT retina infected with $\mathrm{Zic} 2$ virus changed their behavior from crossing into the border to avoidance of the ephrinB2 borders, with only $8 \%$ of their axons projecting into the ephrinB2 zone (Fig. 5A, middle row, left panel). This demonstrates that ectopic expression of Zic2 not only leads to the upregulation of functional EphB1 receptor protein in DT retinal axons but also changes the behavior of DT axons from extension into ephrinB2 regions to the VT or ipsilateral response of repulsion away from its endogenous inhibitory midline cue, ephrinB2 (Fig. 5B).

To confirm that Zic2 acts via regulation of the EphB1 gene, retinal explants from $E p h B 1^{-/-}$E14.5 embryos were infected with either GFP or Zic2 virus. Thirty-three percent of DT neurites from Zic2-infected explants extended across the ephrinB2 substrate border (Fig. $5 A$, bottom left) compared with $36 \%$ of DT axons infected with GFP virus. Twenty-four percent of EphB1 $1^{-/-}$ $\mathrm{VT}$ axons infected with $\mathrm{Zic} 2$ virus projected into the ephrinB2 zone, similar to the percentage of GFP-infected VT axons from wild-type retina that enter the ephrinB2 zone (25\%). As observed in Figure 2, a small percentage of VT axons from $E p h B 1^{-/-}$retina exhibit avoidance of ephrinB2 compared with DT neurites from $E p h B 1^{-1-}$ retina. These data demonstrate that Zic2 controls repulsion of the ipsilateral projection primarily through EphB1 expression, because ectopic Zic2 delivery in the absence of the EphB1 gene does not induce increased avoidance to ephrinB2 borders.

To confirm that EphB1 protein is upregulated on the growth cones of Zic2-infected DT explants, we examined these growth cones at higher magnification as they avoid ephrinB2 borders. EphB1 protein is expressed on DT growth cones after Zic2 virus infection as they encounter and avoid ephrinB2 regions (two representative growth cones in supplemental Fig. $2 \mathrm{~A}$, available at www.jneurosci.org as supplemental material). EphB1 growth cone staining disappears when the EphB1 antibody was preabsorbed with EphB1-Fc (supplemental Fig. $2 B$, available at www.jneurosci.org as supplemental material), confirming that 
EphB1 protein is specifically upregulated in these growth cones. In contrast, DT growth cones infected with GFP did not express EphB1 as they approached an ephrinB2 border (red in supplemental Fig. 2C, available at www.jneurosci.org as supplemental material).

In conclusion, these results together demonstrate that the inhibitory effect of ephrinB2 on VT RGC axons is mediated by EphB1 receptor protein localized on growth cones. Moreover, Zic2 is capable of upregulating EphB1 expression in retinal regions that do not endogenously express EphB1, and Zic2 is sufficient to switch the behavior of RGC axons from indifference to avoidance of the midline cue ephrinB2.

\section{Discussion}

At the optic chiasm midline, EphB1expressing axons from VT retina turn away from ephrinB2-expressing radial glial cells to form the ipsilateral optic tract. Significant progress has been made in identifying guidance molecules that mediate laterality at the CNS midline (Tessier-Lavigne and Goodman, 1996; Williams et al., 2004; Dickson and Gilestro, 2006). However, the intrinsic mechanisms that control the coordinated expression of extracellular guidance molecules on the long trajectory from origin through intermediate and then to final targets is not well understood. Transcription factors are thought to modulate the responses of navigating axons, through regulating the expression of extracellular guidance receptors (Butler and Tear, 2007; Polleux et al., 2007). Our results show that the transcription factor Zic2 can drive the expression of the guidance receptor EphB1, both mRNA and protein, and that EphB1 expression on retinal axon growth cones mediates avoidance of the midline cue ephrinB2.

Transcriptional regulation of EphB1 by Zic2 mediates repulsion at the chiasm midline

A number of transcription factors have been linked to the regulation of axon guidance decisions in the retina (Schulte and Cepko, 2000; Herrera et al., 2003, 2004; Pak et al., 2004). This regulation is thought to occur by transcriptional activation or inhibition of axon guidance molecules, but whether there is a direct link between a transcription factor and the expression of a single or multiple guidance molecule(s) is being investigated. Two examples of such a link are found in motoneurons, in which Lim1 controls dorsoventral projections to the limb by inducing the expression of EphA4 (Kania and Jessell, 2003). In Drosophila, Even-skipped (Eve) controls the balance of the different netrin receptors Unc-5 and DCC in dorsal versus ventral motoneuron trajectories (Labrador et al., 2005). Also in

B
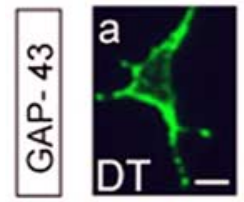
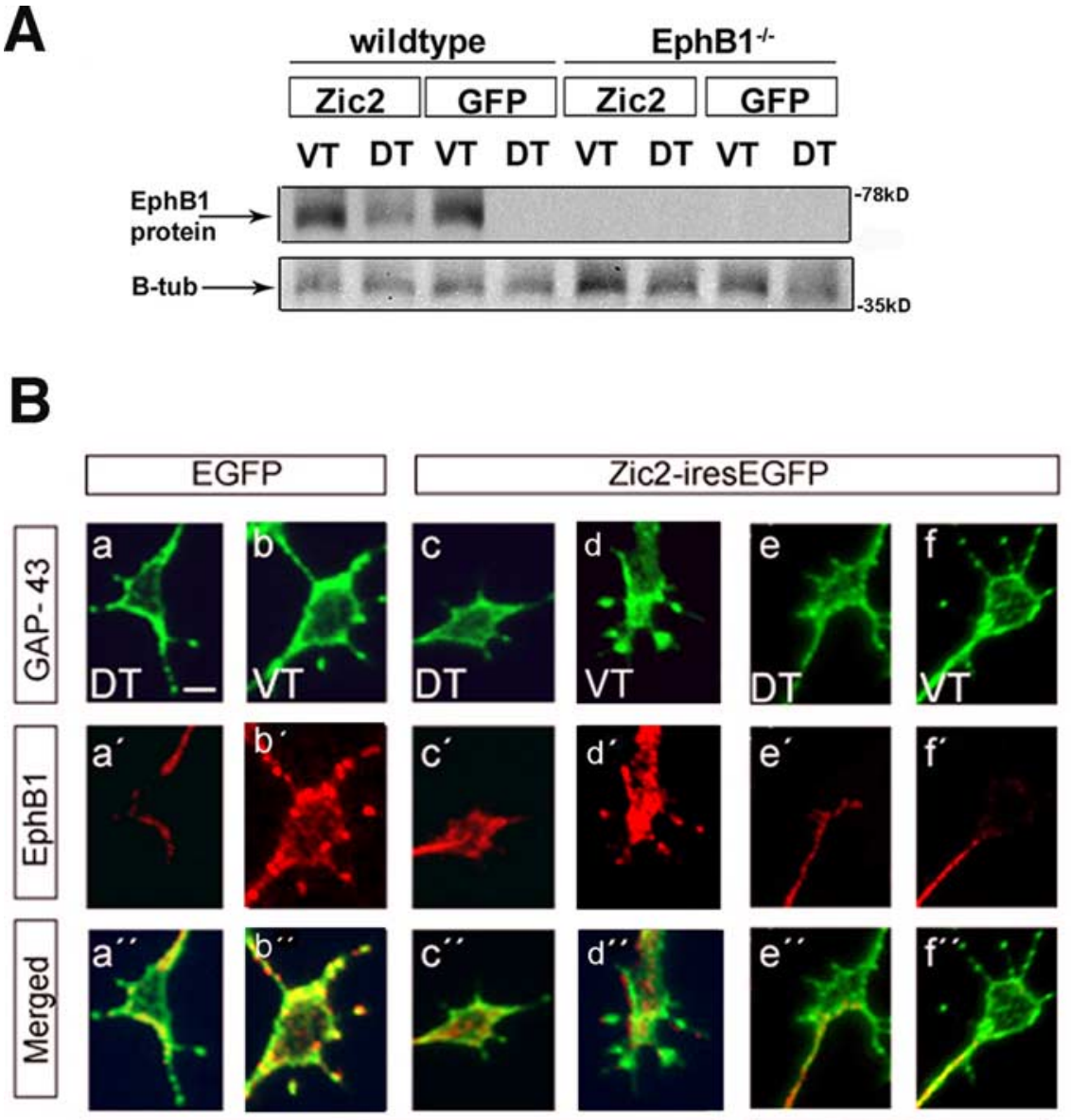

wildtype

EphB1 $^{\prime \prime}$

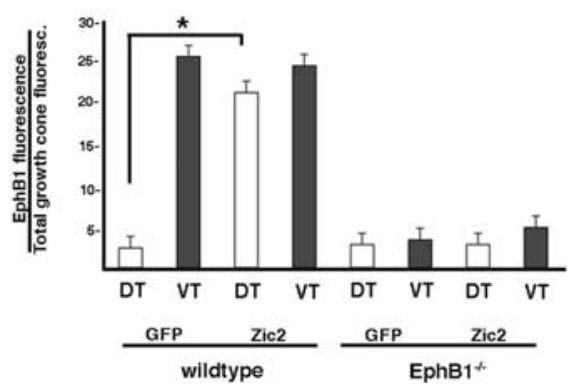

Figure 4. Ectopic Zic2 induces expression of EphB1 protein. $A$, Western blot analysis of $30 \mu \mathrm{g}$ lysates taken from DT and VT explants grown in culture and infected with Zic2 virus or GFP virus. EphB1 protein is upregulated in DT explants after ectopic infection with Zic2 virus (lane 2) but not in DT explants infected with GFP virus (lane 4). EphB1 is detected in VT explants infected with Zic2 (lane 1) or GFP virus (lane 3). $\beta$-Tubulin was used as a loading control, as well as optical density measurements (Bio-Rad). $\boldsymbol{B}$, Immunohistochemistry of growth cones from DT or VT explants infected with GFP $\left(\boldsymbol{a}, \boldsymbol{a}^{\prime}, \boldsymbol{a}^{\prime \prime}, \boldsymbol{b}, \boldsymbol{b}^{\prime}, \boldsymbol{b}^{\prime \prime}\right)$ or Zic2 virus $\left(\boldsymbol{c}, \boldsymbol{c}^{\prime}, \boldsymbol{c}^{\prime \prime}, \boldsymbol{d}, \boldsymbol{d}^{\prime}, \boldsymbol{d}^{\prime \prime}, \boldsymbol{e}, \boldsymbol{e}^{\prime}, \boldsymbol{e}^{\prime \prime}, \boldsymbol{f}, \boldsymbol{f}^{\prime}, \boldsymbol{f}^{\prime}\right)$ and double stained with GAP-43 (green), to visualize growth cones, and with anti-EphB1 antibody (red). EphB1 protein is detected in the growth cones of VT explants infected with GFP virus ( $\boldsymbol{b}^{\prime}$ ) but not in the growth cones of DT explants infected with GFP $\left(\boldsymbol{a}^{\prime}\right)$, as seen in uninfected conditions (Fig. 1A). After Zic2 virus infection, EphB1 receptor protein is expressed in both DT $\left(\boldsymbol{c}^{\prime}\right)$ and VT $\left(\boldsymbol{d}^{\prime}\right)$ growth cones. In growth cones imaged from EphB1 ${ }^{-/-}$animals, EphB1 protein is not detected $\left(\boldsymbol{e}^{\prime}, \boldsymbol{f}^{\prime}\right)$. Scale bar, $10 \mu \mathrm{m}$. $\boldsymbol{C}$, Quantitative data based on fluorescence levels on growth cones from experiments shown in $\boldsymbol{A}$ confirm that EphB1 protein is significantly upregulated in growth cones of axons from DT explants after ectopic expression of Zic2 compared with DT explants infected with GFP virus; these levels are similar to EphB1 protein levels in VT growth cones. EphB1 protein is barely detected in growth cones from $E p h B 1^{-1-}$ retinal axons. EphB1 fluorescent puncta in growth cones was measured over total growth cone fluorescence, as quantified by GAP-43 staining. MetaMorph analysis of $n>$ 58 growth cones, from 6 wells per condition, 3 independent experiments. Error bar indicates SEM. ${ }^{*} p<0.005$.

Drosophila the transcription factor Lola, which has no homolog in vertebrates, controls the expression of both the midline repellant Slit and its axonal receptor Robo (Crowner et al., 2002).

Based on spatiotemporal expression patterns and loss-of- 
A

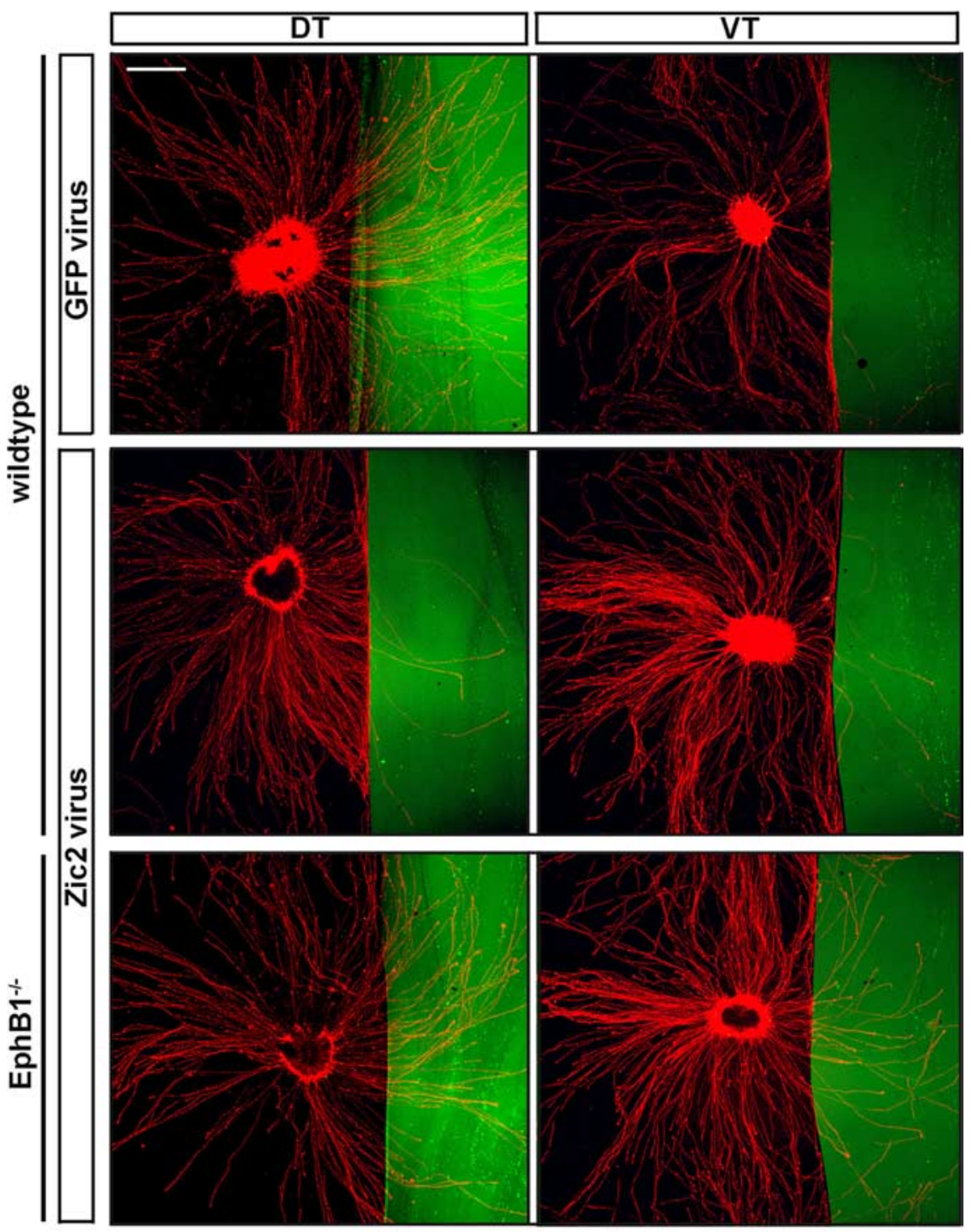

B

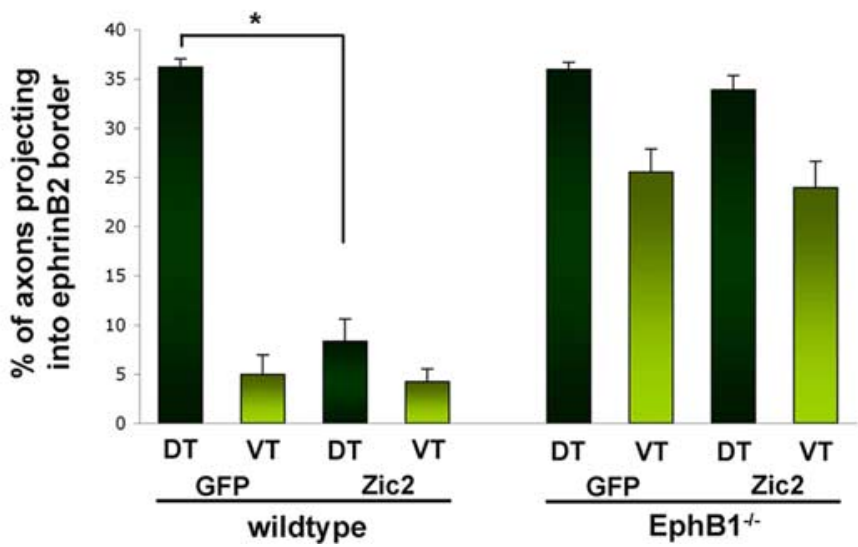

Figure 5. Ectopic expression of Zic2 in retinal explants alters the behavior of RGC axons in response to ephrinB2. $A$, In vitro assays of E14.5 retinal explants stained with GAP-43 (red) plated along ephrinB2 borders (green). Top row shows DT and VT explants infected with GFP virus, middle row shows wild-type explants infected with Zic2 GFP virus, and bottom row shows EphB1 ${ }^{-/-}$explants infected with Zic2 GFP virus. In GFP virus-infected DT explants, DT axons cross into the ephrinB2 border (top left), identical to the uninfected condition (Fig. $2 A$ ), whereas VT axons infected with GFP virus are inhibited by the border (top right), similar to uninfected explants (Fig. 2A). After infection with Zic2 virus, DT axons avoid entering ephrinB2 regions (middle left). DT EphB1 ${ }^{-/-}$axons grow into ephrinB2 border regions, whereas VT EphB1 ${ }^{-/-}$axons exhibit some avoidance to ephrinB2 function experiments in vivo (Herrera et al., 2003; Williams et al., 2003), we focused on Zic2 as a candidate transcriptional regulator of the EphB1 receptor at a midline intermediate target, the optic chiasm. Our data demonstrates that Zic2 drives the expression of EphB1 on ipsilaterally projecting growth cones, because both mRNA in explants, axons, and growth cones and protein localized to growth cones is upregulated after ectopic Zic2 delivery. This activation is sufficient to change the behavior of retinal axons when confronting the midline cue ephrinB2. Furthermore, Zic2 induces repulsion by acting on the EphB1 gene, as proven by analysis of the $E p h B 1^{-/-}$ retina, in which there is no enhancement of avoidance to ephrinB2 after Zic2 ectopic expression. This result indicates tight transcriptional control over the expression of a guidance receptor important for decisions at the vertebrate midline.

Whether Zic2 functions strictly through a direct pathway leading to EphB1 expression or whether Zic2 interacts with other transcription factors that direct crossing at the chiasm midline is not understood. The LIM homeodomain transcription factor Islet2 is a transcription factor that has been implicated in mediating crossing decisions at the midline (Pak et al., 2004). Islet 2 is expressed in RGCs from non-VT retina throughout RGC axonogenesis and in lateborn VT RGCs (E17.5 to postnatal day 0), all of which cross the midline (Williams et al., 2006). Interestingly, Islet $2^{-/-}$mice exhibit an increase in the number of ipsilateral axons originating only from the VT retina, with a concomitant increase in $\mathrm{Zic} 2$ and EphB1 expression in VT retina (Pak et al., 2004). Islet2 has therefore been suggested to repress the guidance program for uncrossed RGCs that involves the regulation of Zic2 and/or EphB1 but exclusively in VT retina. It will be of interest to deter-

\footnotetext{
(bottom row). Scale bar, $500 \mu \mathrm{m}$. B, Quantification of the average area of $\mathrm{RGC}$ axons that enter the border region from pooled retinal explant experiments, as calculated in Figure 2 (for details, see supplemental Fig. 1, available at www. jneurosci.org as supplemental material). In DT explants, $\sim 36 \%$ of total axons project into the ephrinB2 border, whereas $<5 \%$ of VT axons enter the border. After Zic2 virus infection, DT axons avoid ephrinB2 borders with similar repulsion as VT axons, and only 5\% enter ephrinB2 regions. DT EphB1 ${ }^{-1-}$ axons grow into the border region, in both GFP and Zic2 infected conditions, with no additional avoidance after Zic2 ectopic delivery. Of note, there is a small increase in avoidance in EphB1 ${ }^{-1-}$ VT axons ( $~ 24 \%$ of axons project into borders) compared with EphB1 ${ }^{-1-}$ DT axons ( $~ 34 \%$ axons enter border) and is statistically significant $(p<0.005) . n>18$ explants in each condition, 5 independent experiments. Error bars indicate SEM. ${ }^{*} p<0.0005$.
} 
mine whether Islet 2 can repress expression of EphB1 protein through its interaction on Zic2 and to dissect whether Zic2 regulates factors mediating midline crossing (Williams et a., 2006).

\section{Zic2 may be involved in the regulation of other target genes} Although our results demonstrate that EphB1 is one target of Zic2, we do not know whether Zic2 binds directly to 5' upstream regions of the EphB1 gene or whether Zic2 has other target genes. Our results do not address whether Zic2 directly activates the EphB1 gene. The molecular mechanisms of Zic2 action during development remain unclear. Only a handful of direct targets for Zic2 have been identified (Yang et al., 2000; Salero et al., 2001; Sakurada et al., 2005), and an "optimal" consensus target binding sequence for Zic2 proteins is unknown. It has been suggested that its activation of target genes may be by unconventional means, such as recruitment of a DNA/RNA helicase, RHA (Ishiguro et al., 2007; Ishiguro and Aruga, 2008).

It is possible that $\mathrm{Zic} 2$ controls the expression of other guidance molecules, because it can regulate a broad range of target genes in other tissues (Nagai et al., 2000; Aruga et al., 2002a,b) as a result of its involvement in multiple phases of neural development (Aruga, 2004; Merzdorf, 2007). In fact, during development, the expression of Zic2 and EphB1 does not overlap exclusively and the expression of Zic2 has been found in areas of the brain lacking EphB1 expression, and EphB1 is expressed in regions that do not express Zic2 (García-Frigola et al., 2008) (R. Lee, A. Rebsam, and C. Mason, unpublished observations). Furthermore, in utero electroporation of Zic2 into E13 retina in vivo induces a strong ipsilateral projection compared with the increase in the ipsilateral projection after electroporation of EphB1 (García-Frigola et al., 2008) (T. Petros and C. Mason, unpublished results), supporting the view that Zic2 may regulate target genes in addition to EphB1, either other transcriptional regulators or guidance factors that mediate pathfinding decisions at the midline.

Thus, a complete understanding of transcriptional control over guidance factors will rely on unraveling their specific relationship and function, at each intermediate and final target, for there is likely a unique set of directives for each locus. Nevertheless, our data in vitro and data from gain-of-function in vivo (García-Frigola et al., 2008) highlight one example of this relationship, whereby expression of the guidance receptor EphB1 can be controlled at an intermediate target by a single transcription factor, Zic2, to function in midline avoidance.

\section{EphB1 may be regulated by additional mechanisms for the expression of functional protein in growth cones}

In this study, we have demonstrated that EphB1 protein is expressed and localized to VT growth cones and is absent from growth cones in EphB1 $1^{-/-}$VT explants. The presence or absence of EphB1 protein mediates the repulsive behavior of growth cones encountering the midline cue ephrinB2. This finding is significant because previous reports have focused only on the expression of EphB1 mRNA, which is not equivalent to the presence or functional role of a protein.

Although our in vitro assay is a simplified, reductionist model, it allows examination of a single receptor-ligand pair, as growth cones make a binary decision to cross into or avoid ephrinB2 regions. In addition, exogenous genes can be delivered to specified retinal segments, in which the expression of other Ephs and ephrins are known (Luo and Flanagan, 2007).

Of note, when retinal explants from $E p h B 1^{-/-}$animals are grown along borders of ephrinB2 regions, most DT and VT axons cross the border, but some VT axons from EphB1 ${ }^{-1-}$ animals continue to avoid the border. This is similar to the scenario in EphB1 ${ }^{-/-}$animals in vivo, in which a small ipsilateral projection remains (Williams et al., 2003). One possibility is that EphB2, capable of binding ephrinB2 and expressed in a high ventral-lowdorsal gradient during this developmental period in retina (Flanagan and Vanderhaeghen, 1998; McLaughlin and O'Leary, 2005; Flanagan, 2006), can compensate for EphB1 in EphB1 $1^{-/-}$ ventral explants in vitro, contributing to repulsion. Central regions of wild-type and $E p h B 1^{-1-}$ retina plated along ephrinB2 borders also display some degree of repulsion, likely attributable to EphB2 expressed in the central region (R. Lee and T. Petros, unpublished data). However, the contribution of EphB2 in vivo is uncertain because EphB1 $1^{-/} / E p h B 2^{-/-}$mice do not display an additional decrease in ipsilateral projection compared with EphB1 ${ }^{-/-}$alone (Williams et al., 2003). These observations also concur with in vivo data demonstrating that Zic2 may be able to induce avoidance to the midline by means independent of EphB1 (García-Frigola et al., 2008). Thus, the source of this partial repulsion in EphB1 $1^{-/-}$mice remains unknown.

Along with the specific transcriptional activation of EphB1 that we have defined, EphB1 may also be regulated by posttranscriptional steps that occur locally at growth cones, to dynamically alter constituent surface membrane proteins in response to changing environmental signals far from the cell bodies of the RGC axons responding to the cues. This may be particularly relevant for the Eph/ephrin family, because members are expressed in similar neural regions and exhibit promiscuous binding to the same ligand (Davis et al., 1994; Himanen et al., 2004; Pasquale, 2005). By mechanisms such as local translation, trafficking into the membrane or reorganization into surface microdomains to mediate distinct signaling pathways, Ephs could coexist in the same growth cone, either as mRNA or protein contained in separate microdomains to selectively control their functional availability (Castellani et al., 2000; Brittis et al., 2002; Zimmer et al., 2003; Marquardt et al., 2005; Wu et al., 2005; Leung et al., 2006; Yao et al., 2006; Lin and Holt, 2007).

Although our data suggests that Zic2 drives the expression of EphB1 mRNA at the cell body level and these mRNAs are then transported down the axon, it is not clear to what extent encounter with ligand modulates translation locally or whether EphB1 protein is translated in cell bodies and transported to growth cones. Experiments in progress will determine how translation is controlled in the soma and growth cone and the contributions of each, leading to repulsion of RGC growth cones by ephrinB2 at the optic chiasm midline.

\section{References}

Aruga J (2004) The role of Zic genes in neural development. Mol Cell Neurosci 26:205-221.

Aruga J, Inoue T, Hoshino J, Mikoshiba K (2002a) Zic2 controls cerebellar development in cooperation with Zic1. J Neurosci 22:218-225.

Aruga J, Tohmonda T, Hoshino J, Mikoshiba K (2002b) Zicl promotes the expansion of dorsal neural progenitors in spinal cord by inhibiting neuronal differentiation. Dev Biol 244:329-341.

Brittis PA, Lu Q, Flanagan JG (2002) Axonal protein synthesis provides a mechanism for localized regulation at an intermediate target. Cell 110:223-235.

Broihier HT, Kuzin A, Zhu Y, Odenwald W, Skeath JB (2004) Drosophila homeodomain protein Nkx6 coordinates motoneuron subtype identity and axonogenesis. Development 131:5233-5242.

Bundesen LQ, Scheel TA, Bregman BS, Kromer LF (2003) Ephrin-B2 and EphB2 regulation of astrocyte-meningeal fibroblast interactions in response to spinal cord lesions in adult rats. J Neurosci 23:7789-7800. 
Butler SJ, Tear G (2007) Getting axons onto the right path: the role of transcription factors in axon guidance. Development 134:439-448.

Castellani V, Chedotal A, Schachner M, Faivre-Sarrailh C, Rougon G (2000) Analysis of the L1-deficient mouse phenotype reveals cross-talk between Sema3A and L1 signalling pathways in axonal guidance. Neuron 27:237-249.

Crowner D, Madden K, Goeke S, Giniger E (2002) Lola regulates midline crossing of CNS axons in Drosophila. Development 129:1317-1325.

Davis S, Gale NW, Aldrich THZ, Maisonpierre PC, Lhotak V, Pawson T, Goldfarb M, Yancopoulos GD, (1994) Ligands for Eph-related receptor tyrosine kinases that require membrane attachment or clustering for activity. Science 266:816-819.

Dickson BJ, Gilestro GF (2006) Regulation of commissural axon pathfinding by Slit and its Robo receptors. Annu Rev Cell Dev Biol 22:651-675.

Flanagan G, Vanderhaeghen P (1998) The ephrins and Eph receptors in neural development. Annu Rev Neurosci 21:309.

Flanagan JG (2006) Neural map specification by gradient. Curr Opin Neuribiol 16:59-66.

García-Frigola C, Carreres MI, Vegar C, Mason C, Herrera E (2008) Zic2 promotes axonal divergence at the optic chiasm midline by EphB1dependent and independent mechanisms. Development, in press.

Herrera E, Brown LY, Aruga J, Rachel RA, Dolen G, Mikoshiba K, Brown S, Mason CA (2003) Zic2 patterns binocular vision by specifying the uncrossed retinal projection. Cell 114:545-557.

Herrera E, Marcus R, Li S, Williams SE, Erskine L, Lai E, Mason C (2004) Foxd1 is required for proper formation of the optic chiasm. Development 131:5727-5739.

Himanen JP, Chumley MJ, Lackmann M, Li C, Barton WA, Jeffrey PD, Vearing C, Geleick D, Feldheim DA, Boyd AW, Henkemeyer M, Nikolov DB (2004) Repelling class discrimination: ephrin-A5 binds to and activates EphB2 receptor signaling. Nat Neurosci 7:501-509.

Ishiguro A, Aruga J (2008) Functional role of Zic2 phosphorylation in transcriptional regulation. FEBS Lett 582:154-158.

Ishiguro A, Ideta M, Mikoshiba K, Chen DJ, Aruga J (2007) Zic2-dependent transcriptional regulation is mediated by DNA-dependent protein kinase, polymerase and RNA helicase A. J Biol Chem 282:9983-9995.

Jessell TM (2000) Neuronal specification in the spinal cord: inductive signals and transcriptional codes. Nat Rev Genet 1:20-29.

Jevince AR, Kadison SR, Pittman AJ, Chien CB, Kaprielian Z (2006) Distribution of EphB receptors and ephrin-B1 in the developing vertebrate spinal cord. J Comp Neurol 497:734-750.

Kania A, Jessell TM (2003) Topographic motor projections in the limb imposed by LIM homeodomain protein regulation of ephrin-A:EphA interactions. Neuron 38:581-596.

Labrador JP, O'Keefe D, Yoshikawa S, McKinnon RD, Thomas JB, Bashaw GJ (2005) The homeobox transcription factor even-skipped regulates netrin-receptor expression to control dorsal motor-axon projections in Drosophila. Curr Biol 15:1413-1419.

Leung KM, van Horck FP, Lin AC, Allison R, Standart N, Holt CE (2006) Asymmetrical beta-actin mRNA translation in growth cones mediates attractive turning to netrin-1. Nat Neurosci 9:1247-1256.

Lin AC, Holt CE (2007) Local translation and directional steering in axons. EMBO J 26:3729-3736.

Luo L, Flanagan JG (2007) Development of continuous and discrete neural maps. Neuron 56:284-300.

Marquardt T, Shiraski R, Ghosh S, Andrews SE, Carter N, Hunter T, Pfapp SL (2005) Coexpressed EphA receptors and ephrinA ligands mediated op- posing actions on growth cone navigation from distinct membrane domains. Cell 121:127-139.

McLaughlin T, O'Leary DDM (2005) Molecular gradient and development of retinotopic maps. Annu Rev Neurosci 28:327-355.

Merzdorf CS (2007) Emerging roles for zic genes in early development. Dev Dyn 236:922-940.

Nagai T, Aruga J, Minowa O, Sugimoto T, Ohno Y, Noda T, Mikoshiba K (2000) Zic2 regualtes the kinetics of neurulation. Proc Natl Acad Sci USA 97:1618-1623.

Pak W, Hindges R, Lim YS, Pfaff SL, O'Leary DD (2004) Magnitude of binocular vision controlled by Islet-2 repression of a genetic program that specifies laterality of retinal axon pathfinding. Cell 119:567-578.

Pasquale EB (2005) Eph receptor signaling casts a wide net on cell behaviour. Nat Rev Mol Cell Biol 6:589.

Petros TJ, Williams SE, Mason CA (2006) Temporal regulation of EphA4 in astroglia during murine retinal and optic nerve development. Mol Cell Neurosci 32:49-66.

Polleux F, Ince-Dunn G, Ghosh A (2007) Transcriptional regulation of vertebrate axon guidance and synapse formation. Nat Neurosci 8:331-340.

Sakurada T, Mima K, Kurisaki A, Sugino H, Yamauchi T (2005) Neuronal cell type-specific promoter of the alpha CaM kinase II gene is activated by Zic2, a Zic family zinc finger protein. Neurosci Res 53:323-330.

Salero T, Perez-Sen R, Aruga J, Gimenez C, Zafra F (2001) Transcription factors Zicl and Zic2 bind and transactivate the apolipoprotein E gene promoter. J Biol Chem 276:1881-1888.

Schulte D, Cepko CL (2000) Two homeobox genes define the domain of EphA3 expression in the developing chick retina. Development 127:5033-5045.

Shirasaki R, Pfaff SL (2002) Transcriptional codes and the control of neuronal identity. Annu Rev Neurosci 25:251-281.

Tessier-Lavigne M, Goodman CS (1996) The molecular biology of axon guidance. Science 274:1123-1133.

Vidovic M, Marotte LR (2003) Analysis of EphB receptors and their ligands in the developing retinocollicular system of the wallaby reveals dynamic patterns of expression in the retina. Eur J Neurosci 18:1549-1558.

Wang LC, Dani J, Godement P, Marcus RC, Mason CA (1995) Crossed and uncrossed retinal axons respond differently to cells of the optic chiasm midline in vitro. Neuron 15:1349-1364.

Williams SE, Mann F, Erskine L, Sakurai T, Wei S, Rossi DJ, Gale NW, Holt CE, Mason CA, Henkemeyer M (2003) Ephrin-B2 and EphB1 mediate retinal axon divergence at the optic chiasm. Neuron 39:919-935.

Williams SE, Mason CA, Herrera E (2004) The optic chiasm as a midline choice point. Curr Opin Neurobiol 14:51-60.

Williams SE, Grumet M, Colman DR, Henkemeyer M, Mason CA, Sakurai T (2006) A role for Nr-CAM in the patterning of binocular visual pathways. Neuron 50:535-547.

Wu KY, Hengst U, Cox LJ, Macosko EZ, Jeromin A, Urquhart ER, Jaffrey SR (2005) Local translation of RhoA regulates growth cone collapse. Nature 436:1020-1024.

Yang Y, Hwang CK, Junn E, Lee G, Mouradian MM (2000) Zic2 and Sp3 repress Sp1-induced activation of the human D1A dopamine receptor gene. J Biol Chem 275:38863-38869.

Yao J, Sasaki Y, Wen Z, Bassell GJ, Zheng JQ (2006) An essential role for beta-actin mRNA localization and translation in $\mathrm{Ca}^{2+}$-dependent growth cone guidance. Nat Neurosci 9:1265-1273.

Zimmer M, Palmer A, Kohler J, Klein R (2003) EphB-ephrinB bidirectional endocytosis terminates adhesion allowing contact mediated repulsion. Nat Cell Biol 5:869-878. 